\title{
GRANDES OBRAS PÚBLICAS NO BRASIL: SITUAÇÃO E IMPLICAÇÕES NA GOVERNANÇA BRASILEIRA
}

GREAT PUBLIC CONSTRUCTIONS IN BRAZIL: SITUATION AND IMPLICATIONS IN BRAZILIAN GOVERNANCE

\author{
Bruno Cesar Gurski ${ }^{1}$ \\ José Edmilson de Souza-Lima²
}

\section{Resumo}

As grandes obras públicas têm posição estratégica de destaque na perspectiva desenvolvimentista brasileira. No entanto, as irregularidades são constantes, o que ocasiona enormes transtornos socioeconômicos para o País e falência na prestação adequada de serviços públicos à população. Teve-se como objetivo refletir sobre as irregularidades em grandes obras públicas no Brasil, comparando os regimes normativos licitatórios, para entender os motivos pelos quais tal situação é recorrente e apontar diretrizes para minimizar os problemas. Para isso, foi adotada revisão de literatura composta de legislação, livros, documentos, artigos e notícias. Em média, $65 \%$ das obras públicas federais fiscalizadas apresentaram irregularidades graves e apenas $8 \%$ não apresentaram problemas no Brasil. As áreas em que mais ocorrem irregularidades são no processo licitatório, seguido do projeto básico ou executivo. Essas fases são anteriores à execução da obra, por isso revelam problemas do gestor público no planejamento licitatório. Outras áreas que mereceram destaque negativo foram sobrepreço/superfaturamento e execução da obra, que indicam problemas com o contratado. Não houve diferença entre o Regime Diferenciado de Contratações Públicas (RDC) em relação ao regime estabelecido pela Lei $\mathrm{n}$ - 8.666/93 para diminuir irregularidades de quaisquer tipos nas grandes obras públicas no Brasil, entre 2014 e 2016.

Palavras-chave: Licitações; irregularidades; contratos administrativos; fiscalização; Tribunal de Contas da União

\begin{abstract}
\footnotetext{
${ }^{1}$ Doutor em Meio Ambiente. E-mail: brunogurski@ufpr.br

2 Pós-doutor em Meio Ambiente. E-mail: zecae@hotmail.com
}

The great public constructions have a strategic position of prominence in the Brazilian development perspective. However, the irregularities are constant, which causes enormous socioeconomic disturbances for the country and bankruptcy in the adequate provision of public services to the population. The aim was to reflect on the irregularities in great public constructions in Brazil, comparing the normative bidding regimes, to understand the reasons why this situation is recurrent and to set guidelines to minimize the problems. For this, a literature review was adopted, consisting of legislation, books, documents, articles and news. On average, $65 \%$ of the federal public constructions inspected presented serious irregularities and only $8 \%$ did not present problems in Brazil. The areas where irregularities most occur are in the bidding process, followed by the basic or executive project. These phases are prior to the construction execution, so they reveal problems of the public manager in bidding planning. Other areas that deserved negative attention were overprice/overbilling and construction 
execution, which indicate problems with the contractor. There was no difference between the Differentiated Public Procurement Regime (RDC) and the regime established by Law 8,666/93 to reduce irregularities of any kind in great public construction in Brazil, between 2014 and 2016.

Keywords: Bids; irregularities; administrative contracts; oversight; Court Union Accounts

\section{INTRODUÇÃO}

Com a criação do Programa de Aceleração do Crescimento (PAC) em 2007, aliada à realização da Copa do Mundo de 2014 e as Olimpíadas em 2016, houve execução de grandes obras de infraestrutura social, urbana, logística e energética no Brasil que contribuíram de maneira decisiva para aumentar a oferta de empregos e geração de renda, elevação do investimento público e privado, e prestação de serviços públicos essenciais para a população.

Por se tratar de atividade essencial e estratégica para o País, as obras públicas são realizadas em regime de licitação, processo este garantidor de uma série de prerrogativas, direitos, deveres e sanções a todos os agentes participantes. Atualmente, no sistema normativo licitatório brasileiro existem duas leis que se sobressaem no regimento das licitações: Lei no 8.666/1993 que instituiu normas para licitações e contratos da Administração Pública em geral; e mais recentemente a Lei no 12.462/2011 que instituiu o Regime Diferenciado de Contratações Públicas (RDC), que possui como objetivos ampliar a eficiência nas contratações públicas e a competitividade entre os licitantes, buscar a melhor relação entre custos e benefícios para o setor público, incentivar a inovação tecnológica, assegurar tratamento isonômico entre os licitantes e a seleção da proposta mais vantajosa para a administração pública. Resumindo, o sistema normativo licitatório brasileiro foi criado com os objetivos de maximizar a concorrência entre fornecedores, garantir de forma adequada a entrega de bens e serviços à população, diminuir custos nos orçamentos públicos, evitar favorecimentos pessoais, dentre outros. Inclusive com normas sancionadoras e tipificação de crimes para respeitar tal sistema.

A despeito dos avanços obtidos com esse sistema normativo, ao que parece, os objetivos propostos não estão sendo atingidos de forma adequada. Os principais problemas são as irregularidades em obras públicas, que ocasionam enormes transtornos socioeconômicos para o Brasil, desperdício de tempo, receita e pessoal, paralisações, favorecimentos pessoais, enfim, falência do planejamento público e deficiência em prestar o adequado serviço público à população. Além disso, essa problemática normalmente atinge as classes sociais mais carentes, as quais mais necessitam desses serviços. Entender os motivos pelos quais tais fatos ocorrem é 
essencial para apontar soluções a fim de aperfeiçoar a governança brasileira e minimizar os problemas apontados.

Teve-se como objetivo refletir sobre as irregularidades em grandes obras públicas no Brasil, comparando os regimes normativos licitatórios, para entender os motivos pelos quais tal situação é recorrente e apontar diretrizes para minimizar os problemas. Para isso, foi adotada revisão de literatura composta de legislação, livros, documentos, artigos e notícias.

\section{SISTEMA NORMATIVO LICITATÓRIO BRASILEIRO PARA OBRAS PÚBLICAS}

Todo contrato administrativo no Brasil deve ser precedido, via de regra, de licitação (BRASIL, 1988). Licitação é o procedimento administrativo destinado a selecionar a proposta mais vantajosa para a administração pública assegurando o desenvolvimento nacional sustentável, ampla participação dos interessados e tratamento isonômico (JUSTEN FILHO, 2016).

Devido à importância e abrangência do tema, o sistema normativo licitatório brasileiro foi construído obedecendo à lógica hierárquica kelseniana. Atualmente, compete exclusiva e privativamente à União legislar sobre licitações no Brasil. Essa competência foi instituída pela Constituição Federal (CF) de 1988, visto tratar-se de tema extremamente relevante e estratégico para o País, sobretudo para a correta prestação de serviços públicos à população.

Art. 22. Compete privativamente à União legislar sobre:

$[\ldots]$

XXVII - normas gerais de licitação e contratação, em todas as modalidades, para as administrações públicas diretas, autárquicas e fundacionais da União, estados, Distrito Federal e municípios, obedecido o disposto no art. 37, XXI, e para as empresas públicas e sociedades de economia mista, nos termos do art. 173, §1으, III;

Art. 175. Incumbe ao poder público, na forma da lei, diretamente ou sob regime de concessão ou permissão, sempre através de licitação, a prestação de serviços públicos (BRASIL, 1988).

A CF também julgou importante especificar que as contratações devem obedecer a uma série de princípios para garantir a supremacia do interesse público.

Art. 37. A administração pública direta e indireta de qualquer dos Poderes da União, dos Estados, do Distrito Federal e dos Municípios obedecerá aos princípios de legalidade, impessoalidade, moralidade, publicidade e eficiência e, também, ao seguinte: [...]

$X X I$ - ressalvados os casos especificados na legislação, as obras, serviços, compras e alienações serão contratados mediante processo de licitação pública que assegure igualdade de condições a todos os concorrentes, com cláusulas que estabeleçam obrigações de pagamento, mantidas as condições efetivas da proposta, nos termos da lei, o qual somente 
permitirá as exigências de qualificação técnica e econômica indispensáveis à garantia do cumprimento das obrigações (BRASIL, 1988).

A Lei no 8.666/1993 é caracterizada como marco legal das licitações e contratos em geral da Administração Pública no Brasil, regrando todo o procedimento licitatório, inclusive com imposição de sanções administrativas, tipificação de crimes e cominação de penas. Atualmente, esta lei regula a maioria das obras públicas no Brasil, e mesmo quando a regulação é realizada por outra norma, ela tem aplicação subsidiária (JUSTEN FILHO, 2016; MELLO, 2016; PIETRO, 2017).

Art. 39. Os contratos administrativos celebrados com base no Regime Diferenciado de Contratação reger-se-ão pelas normas da Lei no 8.666, de 21 de junho de 1993, com exceção das regras específicas previstas nesta lei (BRASIL, 2011b).

Dentre as principais modalidades de licitação existentes no Brasil, a concorrência é a mais completa e segura. Esta modalidade é necessária em grandes obras públicas, pois envolve valores de grande monta, projetos de grande vulto, serviços públicos essenciais, enfim, estruturas estratégicas para a governança e população. Por isso, deveria ser a modalidade que menos apresenta irregularidades.

Art. 22 São modalidades de licitação:

I - concorrência; [...]

$\S 1^{\circ}$ Concorrência é a modalidade de licitação entre quaisquer interessados que, na fase inicial de habilitação preliminar, comprovem possuir os requisitos mínimos de qualificação exigidos no edital para execução de seu objeto.

Art. 23 As modalidades de licitação a que se referem os incisos I a III do artigo anterior serão determinadas em função dos seguintes limites, tendo em vista o valor estimado da contratação:

I - para obras e serviços de engenharia: [...]

c) concorrência - acima de $R \$ 1.500 .000,00$ (um milhão e quinhentos mil reais) (BRASIL, 1993).

Não serão tratadas outras modalidades de licitação instituídas pela Lei no 8.666/93 como tomada de preços, convite, concurso, leilão, nem outras modalidades instituídas por leis federais como o pregão, instituído pela Lei no 10.520/02, pois todas as obras e serviços de engenharia analisados neste artigo possuem alto custo econômico, elevada complexidade técnica e grande impacto social que justificam a adoção apenas da modalidade concorrência, inclusive no Regime Diferenciado de Contratação, que é a mais complexa e completa modalidade de licitação.

Com o advento do Programa de Aceleração do Crescimento (PAC) em 2007, aliada à realização da Copa do Mundo de 2014 e Olimpíadas em 2016 o Brasil aumentou muito o número de grandes obras públicas no País, com necessidade de rápida execução e conclusão. 
Por consequência, o legislador brasileiro considerou que, apesar de todo avanço e benefícios trazidos pela Lei no 8.666/93, ela não estava proporcionando a celeridade necessária para a entrega das obras públicas para os grandes eventos que iriam ocorrer no País. Neste contexto, surgiu a Lei no 12.462/2011, que instituiu o Regime Diferenciado de Contratações Públicas (RDC), a princípio aplicável apenas a essas ocasiões especiais, mas que por flexibilizar certas normas da Lei no 8.666/93, trouxe celeridade e eficiência sem olvidar da segurança fornecida pela lei anterior. Por isso, essa lei sofreu inúmeras alterações em curto período de tempo para ser aplicável em outras obras públicas, sendo considerada atualmente como o novo regramento aplicável às obras públicas no Brasil (CELESTINO, 2012; BRASIL, 2013b; ALTOUNIAN, 2016; BRASIL, 2016b).

Art. 1 É instituído o Regime Diferenciado de Contratações Públicas (RDC), aplicável exclusivamente às licitações e contratos necessários à realização:

I - dos Jogos Olímpicos e Paraolímpicos de 2016, constantes da Carteira de Projetos Olímpicos a ser definida pela Autoridade Pública Olímpica (APO); e

II - da Copa das Confederações da Federação Internacional de Futebol Associação - Fifa 2013 e da Copa do Mundo Fifa 2014, definidos pelo Grupo Executivo - Gecopa 2014 do Comitê Gestor instituído para definir, aprovar e supervisionar as ações previstas no Plano Estratégico das Ações do Governo Brasileiro para a realização da Copa do Mundo Fifa 2014 CGCOPA 2014, restringindo-se, no caso de obras públicas, às constantes da matriz de responsabilidades celebrada entre a União, Estados, Distrito Federal e Municípios;

III - de obras de infraestrutura e de contratação de serviços para os aeroportos das capitais dos Estados da Federação distantes até $350 \mathrm{~km}$ (trezentos e cinquenta quilômetros) das cidades sedes dos mundiais referidos nos incisos I e II.

IV - das ações integrantes do Programa de Aceleração do Crescimento (PAC) (Incluído pela Lei no 12.688, de 2012)

$V$ - das obras e serviços de engenharia no âmbito do Sistema Único de Saúde - SUS. (Incluído pela Lei no 12.745, de 2012)

$\forall 1$ das obras e serviços de engenharia para construção, ampliaçãa-e refma de estabelecimes penais e unidades de atendimento socioeducativo. (Incluído pela Medida Provisória no 630, de 2013)

V1 das obras e serviços de engharia construção, ampliaçãoe reforma de estabelecimentos penais e unidades de atendimento

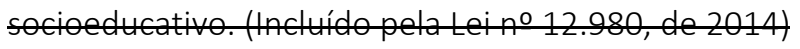

V1- das obras e serviços de engenharia para construção, ampliação e reforma de estabelecimentos penais e unidades de atendimento socioeducativo; e (Redação dada pela Medida Provisória no 678, de 2015) VII ações no âmbito da Segurança Pública. (Incluído pela Medida Provisória no 678, de 2015) 
VI - das obras e serviços de engenharia para construção, ampliação e reforma e administração de estabelecimentos penais e de unidades de atendimento socioeducativo; (Incluído pela Lei no 13.190, de 2015)

VII - das ações no âmbito da segurança pública; (Incluído pela Lei no 13.190, de 2015)

VIII - das obras e serviços de engenharia, relacionadas a melhorias na mobilidade urbana ou ampliação de infraestrutura logística; e (Incluído pela Lei no 13.190, de 2015)

IX - dos contratos a que se refere o art. 47-A. (Incluído pela Lei no 13.190, de 2015)

$X$ - das ações em órgãos e entidades dedicados à ciência, à tecnologia e à inovação. (Incluído pela Lei no 13.243, de 2016)

$\S 1$ ㅇ O RDC tem por objetivos:

I - ampliar a eficiência nas contratações públicas e a competitividade entre os licitantes;

II - promover a troca de experiências e tecnologias em busca da melhor relação entre custos e benefícios para o setor público;

III - incentivar a inovação tecnológica; e

IV - assegurar tratamento isonômico entre os licitantes e a seleção da proposta mais vantajosa para a administração pública.

$\S 2$ ○ A opção pelo RDC deverá constar de forma expressa do instrumento convocatório e resultará no afastamento das normas contidas na Lei no 8.666, de 21 de junho de 1993, exceto nos casos expressamente previstos nesta Lei.

ร $3^{\theta}$ Além das hipóteses previstas nocaput, ORDC também á aplicávelìs Hicitaçeses e contratos necescários ì realização de obras e serviços de engenharia no âmbito dos sistemas públicos de ensino. (Incluído pela Lei no 12.722 , de 2012 )

§ 3o Além das hipóteses previstas no caput, o RDC também é aplicável às licitações e aos contratos necessários à realização de obras e serviços de engenharia no âmbito dos sistemas públicos de ensino e de pesquisa, ciência e tecnologia. (Redação dada pela Lei no 13.190, de 2015)

$[\ldots]$

Art. 3o As licitações e contratações realizadas em conformidade com o RDC deverão observar os princípios da legalidade, da impessoalidade, da moralidade, da igualdade, da publicidade, da eficiência, da probidade administrativa, da economicidade, do desenvolvimento nacional sustentável, da vinculação ao instrumento convocatório e do julgamento objetivo (BRASIL, 2011b).

Além dos princípios invocados pelo RDC, este regime apresenta certas inovações em relação ao regime geral de licitação imposto pela Lei no 8.666/93, dentre as quais: caráter sigiloso do orçamento, inversão de fases, regime de contratação integrada, remuneração variável, Sistema de Registro de Preços, pré-qualificação permanente, incentivo à inovação tecnológica, critério do maior retorno econômico, prazo recursal único, dentre outras (BRASIL, 2011b; CELESTINO, 2012). 


\section{SITUAÇÃO E CONTROLE DAS GRANDES OBRAS PÚBLICAS NO BRASIL PELO TRIBUNAL DE CONTAS DA UNIÃO}

A Constituição Federal estabelece que a fiscalização contábil, financeira e orçamentária das obras públicas construídas no âmbito da União seja realizada por um sistema de controle interno e externo. O controle interno se dá em entidade do mesmo Poder, e o externo quando o agente é de outro Poder ou externo à Administração Pública:

Art. 70. A fiscalização contábil, financeira, orçamentária, operacional e patrimonial da União e das entidades da administração direta e indireta, quanto à legalidade, legitimidade, economicidade, aplicação das subvenções e renúncia de receitas, será exercida pelo Congresso Nacional, mediante controle externo, e pelo sistema de controle interno de cada Poder.

Parágrafo único. Prestará contas qualquer pessoa física ou jurídica, pública ou privada, que utilize, arrecade, guarde, gerencie ou administre dinheiros, bens e valores públicos ou pelos quais a União responda, ou que, em nome desta, assuma obrigações de natureza pecuniária (BRASIL, 1988).

Neste sentido, o Tribunal de Contas da União (TCU) atua no controle externo das obras

públicas, pois são atos provenientes do Poder Executivo:

Art. 71. O controle externo, a cargo do Congresso Nacional, será exercido com o auxílio do Tribunal de Contas da União, ao qual compete: [..]

II - julgar as contas dos administradores e demais responsáveis por dinheiros, bens e valores públicos da administração direta e indireta, acrescentadas as fundações e sociedades instituídas e mantidas pelo Poder Público federal, e as contas daqueles que derem causa a perda, extravio ou outra irregularidade de que resulte prejuízo ao erário público; $[\ldots]$

IV - realizar, por iniciativa própria, da Câmara dos Deputados, do Senado Federal, de Comissão técnica ou de inquérito, inspeções e auditorias de natureza contábil, financeira, orçamentária, operacional e patrimonial, nas unidades administrativas dos Poderes Legislativo, Executivo e Judiciário, e demais entidades referidas no inciso II; [..]

VII - prestar as informações solicitadas pelo Congresso Nacional, por qualquer de suas Casas, ou por qualquer das respectivas Comissões, sobre a fiscalização contábil, financeira, orçamentária, operacional e patrimonial e sobre resultados de auditorias e inspeções realizadas;

VIII - aplicar aos responsáveis, em caso de ilegalidade de despesa ou irregularidade de contas, as sanções previstas em lei, que estabelecerá, entre outras cominações, multa proporcional ao dano causado ao erário; IX - assinar prazo para que o órgão ou entidade adote as providências necessárias ao exato cumprimento da lei, se verificada ilegalidade;

$X$ - sustar, se não atendido, a execução do ato impugnado, comunicando a decisão à Câmara dos Deputados e ao Senado Federal; [...]

$\S 4$ o - O Tribunal encaminhará ao Congresso Nacional, trimestral e anualmente, relatório de suas atividades (BRASIL, 1988). 
Mais especificamente em relação às grandes obras públicas federais, que normalmente estão contidas em três leis orçamentárias: Plano Plurianual, Lei de Diretrizes Orçamentárias (LDO) e Lei do Orçamento Anual (LOA) - cabe a uma comissão mista analisar a situação e fiscalização realizada pelo TCU:

Art. 166. Os projetos de lei relativos ao plano plurianual, às diretrizes orçamentárias, ao orçamento anual e aos créditos adicionais serão apreciados pelas duas Casas do Congresso Nacional, na forma do regimento comum.

$\S$ 1ㅇ Caberá a uma Comissão mista permanente de Senadores e Deputados:

I - examinar e emitir parecer sobre os projetos referidos neste artigo e sobre as contas apresentadas anualmente pelo Presidente da República;

II - examinar e emitir parecer sobre os planos e programas nacionais, regionais e setoriais previstos nesta Constituição e exercer o acompanhamento e a fiscalização orçamentária, sem prejuízo da atuação das demais comissões do Congresso Nacional e de suas Casas, criadas de acordo com o art. 58 (BRASIL, 1988).

Como o TCU fiscaliza centenas de obras em todo o território brasileiro, as

irregularidades devem ser apontadas a essa comissão mista:

Art. $59[\ldots]$

$\S 1$ 1 Os Tribunais de Contas alertarão os Poderes ou órgãos referidos no art. 20 quando constatarem: [...]

$V$ - fatos que comprometam os custos ou os resultados dos programas ou indícios de irregularidades na gestão orçamentária. (BRASIL, 2000).

Desde 1997, todas as LDO's estabelecem quais os parâmetros que devem conter nos relatórios de obras públicas a ser entregue à Comissão Mista de Planos, Orçamentos Públicos e Fiscalização do Congresso Nacional - CMO. A título de exemplo, a última LDO de 2016 estabeleceu:

Art. 119. Para fins do disposto no inciso $\vee$ do $\S 1$ 으 do art. 59 da Lei de Responsabilidade Fiscal e no art. 9o desta Lei, o Tribunal de Contas da União encaminhará:

$[\ldots]$

II - à Comissão Mista a que se refere o § 10 do art. 166 da Constituição, até setenta dias após o encaminhamento do Projeto de Lei Orçamentária, a relação atualizada de contratos, convênios, etapas, parcelas ou subtrechos relativos aos subtítulos nos quais forem identificados indícios de irregularidades graves, classificados na forma disposta nos incisos IV, $\mathrm{V}$ e VI do $\S 1$ o do art. 117, bem como a relação daqueles que, embora tenham tido recomendação de paralisação da equipe de auditoria, não foram objeto de decisão monocrática ou colegiada no prazo previsto no $\S$ 9o do art. 117, acompanhadas de cópias em meio eletrônico das decisões monocráticas e colegiadas, dos Relatórios e Votos que as fundamentarem e dos relatórios de auditoria das obras e dos serviços fiscalizados (BRASIL, 2015b). 
Em detrimento deste arcabouço normativo que determinou esses deveres ao TCU surgiu o relatório consolidado sobre as fiscalizações de obras (Fiscobras ${ }^{3}$ ): plano de fiscalização anual que engloba um conjunto de ações de controle do TCU com o objetivo de verificar o processo de execução de obras públicas financiadas total ou parcialmente com recursos da União (BRASIL, 2016b).

Importante frisar que o TCU possui metodologia própria imposta por lei para realizar os relatórios, e ressalta-se que não são todas as obras públicas que são fiscalizadas, pois o custo econômico e de pessoal não justifica as ações. Na verdade, a fiscalização é realizada por amostragem, em que a seleção das obras se dá por diversos critérios técnicos. Segundo a LDO 2016, a seleção das obras e serviços a serem fiscalizados deve considerar, entre outros fatores: o valor autorizado e empenhado no exercício anterior e no exercício atual; os projetos de grande vulto; a regionalização do gasto; o histórico de irregularidades pendentes; e a reincidência de irregularidades cometidas. No entanto, essas fiscalizações fornecem indicativos de como está o planejamento da governança brasileira (BRASIL, 2015b).

Pode ser uma tendência em detrimento do número de obras existentes em cada região brasileira, mas o Nordeste foi a região onde ocorreram o maior número de fiscalizações, enquanto o Sul a menor (Tabela 1). Pode ser devido também à distribuição não uniforme no número de estados por região. Os estados que mereceram destaque na quantidade de fiscalizações foram Rio de Janeiro, Bahia e Pernambuco, possivelmente pela realização das Olimpíadas 2016 e Copa do Mundo 2014, respectivamente.

\section{Tabela 1 - Distribuição geográfica unitária das fiscalizações de obras públicas} do Fiscobras no Brasil

\begin{tabular}{|c|c|c|c|c|c|c|c|}
\hline Região/UF & 2011 & 2012 & 2013 & 2014 & 2015 & 2016 & Total \\
\hline Norte & 36 & 54 & 19 & 18 & 14 & 12 & 153 \\
\hline AC & 6 & 6 & 1 & 1 & 2 & 3 & 19 \\
\hline AM & 7 & 23 & 4 & 4 & 2 & 1 & 41 \\
\hline AP & 2 & 1 & 1 & 2 & 4 & 3 & 12 \\
\hline PA & 5 & 9 & 7 & 4 & 2 & 2 & 29 \\
\hline RO & 7 & 6 & 2 & 1 & 2 & 1 & 19 \\
\hline RR & 4 & 3 & 1 & 3 & 1 & 1 & 13 \\
\hline TO & 5 & 6 & 3 & 3 & 1 & 1 & 19 \\
\hline
\end{tabular}

\footnotetext{
3 Todos os Fiscobras têm como fonte acórdãos (BRASIL, 2011; BRASIL, 2012; BRASIL, 2013; BRASIL, 2014; BRASIL, 2015; BRASIL, 2016) que são discutidos e julgados pelo plenário do Tribunal de Contas da União, ou seja, há relatório e declaração de votos, em que os ministros emitem seus pareceres para aprovação desse relatório. Posteriormente, o acórdão é encaminhado e servirá de base à Comissão Mista de Planos, Orçamentos Públicos e Fiscalização do Congresso Nacional para adoção das medidas cabíveis.
} 


\begin{tabular}{|c|c|c|c|c|c|c|c|}
\hline Nordeste & 69 & 73 & 56 & 41 & 38 & 45 & 322 \\
\hline $\mathrm{AL}$ & 6 & 8 & 3 & 3 & 2 & 1 & 23 \\
\hline BA & 11 & 18 & 12 & 9 & 6 & 9 & 65 \\
\hline $\mathrm{CE}$ & 10 & 8 & 11 & 5 & 11 & 5 & 50 \\
\hline MA & 3 & 9 & 2 & 2 & 2 & 5 & 23 \\
\hline PB & 8 & 4 & 1 & 3 & 2 & 0 & 18 \\
\hline$P E$ & 11 & 13 & 11 & 10 & 4 & 14 & 63 \\
\hline $\mathrm{PI}$ & 3 & 7 & 5 & 6 & 2 & 4 & 27 \\
\hline RN & 11 & 5 & 8 & 3 & 5 & 5 & 37 \\
\hline SE & 6 & 1 & 3 & 0 & 4 & 2 & 16 \\
\hline Centro-Oeste & 35 & 25 & 16 & 10 & 10 & 12 & 108 \\
\hline DF & 4 & 1 & 1 & 1 & 3 & 2 & 12 \\
\hline GO & 13 & 9 & 9 & 4 & 3 & 8 & 46 \\
\hline MS & 10 & 6 & 1 & 1 & 1 & 1 & 20 \\
\hline MT & 8 & 9 & 5 & 4 & 3 & 1 & 30 \\
\hline Sudeste & 60 & 38 & 34 & 21 & 26 & 34 & 213 \\
\hline ES & 8 & 7 & 1 & 3 & 3 & 1 & 23 \\
\hline MG & 15 & 12 & 14 & 4 & 1 & 10 & 56 \\
\hline RJ & 22 & 13 & 12 & 7 & 13 & 14 & 81 \\
\hline SP & 15 & 6 & 7 & 7 & 9 & 9 & 53 \\
\hline Sul & 30 & 10 & 11 & 12 & 9 & 23 & 95 \\
\hline PR & 9 & 2 & 2 & 4 & 3 & 6 & 26 \\
\hline RS & 16 & 7 & 5 & 4 & 5 & 14 & 51 \\
\hline SC & 5 & 1 & 4 & 4 & 1 & 3 & 18 \\
\hline Total & 230 & 200 & 136 & 102 & 97 & 126 & 891 \\
\hline
\end{tabular}

Fonte: adaptado de BRASIL (2011); BRASIL (2012); BRASIL (2013); BRASIL (2014); BRASIL (2015); BRASIL (2016).

Na dotação orçamentária, que consiste no valor estimado das obras fiscalizadas, como esperado, o Sudeste se sobressaiu, seguido do Nordeste, devido sobretudo ao Rio de Janeiro e Pernambuco, que nos seis anos analisados, somaram quase setenta bilhões e quarenta bilhões de reais, respectivamente, em dotação orçamentária (Tabela 2).

Tabela 2 - Dotação orçamentária ( $R \$$ ) das fiscalizações de obras públicas do Fiscobras no Brasil

\begin{tabular}{|c|c|c|c|c|c|c|}
\hline $\begin{array}{c}\text { Região/ } \\
\text { UF }\end{array}$ & 2011 & 2012 & 2013 & 2014 & 2015 & 2016 \\
\hline Norte & $\begin{array}{c}1.990 .289 .9 \\
05\end{array}$ & $\begin{array}{c}2.120 .857 .9 \\
16\end{array}$ & $\begin{array}{c}1.497 .708 .0 \\
25\end{array}$ & $\begin{array}{c}807.740 .46 \\
6\end{array}$ & $\begin{array}{c}994.570 .96 \\
3\end{array}$ & $\begin{array}{c}1.066 .848 .3 \\
50\end{array}$ \\
\hline AC & $\begin{array}{c}182.396 .50 \\
5\end{array}$ & $\begin{array}{c}143.185 .09 \\
8\end{array}$ & 54.698 .013 & $0 *$ & $\begin{array}{c}314.315 .44 \\
5\end{array}$ & $\begin{array}{c}249.127 .34 \\
1\end{array}$ \\
\hline AM & $\begin{array}{c}447.960 .07 \\
3\end{array}$ & $\begin{array}{c}366.079 .36 \\
5\end{array}$ & $\begin{array}{c}451.221 .59 \\
1\end{array}$ & 20.756 .444 & 73.065 .445 & 330.220 \\
\hline AP & $\begin{array}{c}128.239 .50 \\
0\end{array}$ & 40.219 .212 & 30.900 .091 & $\begin{array}{c}173.461 .09 \\
0\end{array}$ & $\begin{array}{c}364.067 .73 \\
8\end{array}$ & $\begin{array}{c}225.065 .97 \\
1\end{array}$ \\
\hline
\end{tabular}




\begin{tabular}{|c|c|c|c|c|c|c|}
\hline PA & $\begin{array}{c}357.420 .75 \\
0\end{array}$ & $\begin{array}{c}958.945 .00 \\
8\end{array}$ & $\begin{array}{c}550.560 .00 \\
0\end{array}$ & $\begin{array}{c}202.616 .00 \\
0\end{array}$ & $\begin{array}{c}166.991 .44 \\
5\end{array}$ & $\begin{array}{c}371.200 .48 \\
6\end{array}$ \\
\hline RO & $\begin{array}{c}184.185 .24 \\
8\end{array}$ & $\begin{array}{c}299.040 .85 \\
4\end{array}$ & $\begin{array}{c}203.490 .06 \\
3\end{array}$ & 31.870 .700 & 70.000 .000 & 28.796 .928 \\
\hline RR & 64.090 .829 & 21.224.295 & $\begin{array}{c}109.458 .26 \\
7\end{array}$ & 2 & 3.065 .445 & $\begin{array}{c}150.000 .00 \\
0\end{array}$ \\
\hline TO & $\begin{array}{c}625.997 .00 \\
0\end{array}$ & $\begin{array}{c}292.164 .08 \\
2\end{array}$ & 97.380 .000 & $0^{*}$ & 3.065 .445 & 42.327 .404 \\
\hline $\begin{array}{c}\text { Nordest } \\
\mathrm{e}\end{array}$ & $\begin{array}{c}16.197 .581 . \\
061\end{array}$ & $\begin{array}{c}19.623 .266 \\
177\end{array}$ & $\begin{array}{c}15.365 .360 \\
353\end{array}$ & 24 & $\begin{array}{c}5.429 .189 .1 \\
83\end{array}$ & $\begin{array}{c}4.303 .690 .9 \\
66\end{array}$ \\
\hline$A L$ & $\begin{array}{c}449.973 .15 \\
9\end{array}$ & $\begin{array}{c}810.343 .33 \\
8\end{array}$ & $\begin{array}{c}565.200 .00 \\
0\end{array}$ & $0^{*}$ & $\begin{array}{c}308.500 .00 \\
0\end{array}$ & 87.538 .733 \\
\hline BA & $\begin{array}{c}1.288 .534 .4 \\
15\end{array}$ & $\begin{array}{c}2.173 .437 .8 \\
23\end{array}$ & $\begin{array}{c}1.495 .810 .3 \\
64\end{array}$ & $\begin{array}{c}651.050 .83 \\
8\end{array}$ & $\begin{array}{c}1.398 .321 .1 \\
40\end{array}$ & $\begin{array}{c}611.557 .40 \\
6\end{array}$ \\
\hline CE & $\begin{array}{c}702.219 .41 \\
4\end{array}$ & $\begin{array}{c}905.411 .39 \\
5\end{array}$ & $\begin{array}{c}253.474 .82 \\
5\end{array}$ & $\begin{array}{c}359.280 .14 \\
4\end{array}$ & $\begin{array}{c}1.716 .989 .6 \\
75\end{array}$ & $\begin{array}{c}189.419 .03 \\
0\end{array}$ \\
\hline MA & $\begin{array}{c}1.271 .160 .8 \\
72\end{array}$ & $\begin{array}{c}2.848 .444 .8 \\
85\end{array}$ & $\begin{array}{c}494.364 .00 \\
0\end{array}$ & 20.100 .000 & $\begin{array}{c}201.191 .44 \\
5\end{array}$ & $\begin{array}{c}429.247 .42 \\
1\end{array}$ \\
\hline PB & $\begin{array}{c}193.993 .80 \\
0\end{array}$ & $\begin{array}{c}564.667 .21 \\
4\end{array}$ & $\begin{array}{c}120.000 .00 \\
0\end{array}$ & $\begin{array}{c}379.036 .23 \\
2\end{array}$ & 54.940 .445 & 0* \\
\hline PE & $\begin{array}{c}11.735 .049 \\
067\end{array}$ & $\begin{array}{c}10.956 .697 \\
775\end{array}$ & $\begin{array}{c}10.808 .692 \\
000\end{array}$ & $\begin{array}{c}788.799 .87 \\
2\end{array}$ & 4 & 7 \\
\hline $\mathrm{PI}$ & $\begin{array}{c}186.261 .45 \\
3\end{array}$ & $\begin{array}{c}493.757 .47 \\
2\end{array}$ & $\begin{array}{c}859.398 .26 \\
7\end{array}$ & $\begin{array}{c}886.479 .48 \\
2\end{array}$ & 65.092 .940 & 62.628 .848 \\
\hline RN & $\begin{array}{c}223.808 .94 \\
0\end{array}$ & $\begin{array}{c}828.076 .27 \\
3\end{array}$ & $\begin{array}{c}686.288 .98 \\
9\end{array}$ & 19.303 .554 & $\begin{array}{c}232.640 .14 \\
8\end{array}$ & $\begin{array}{c}1.046 .598 .9 \\
82\end{array}$ \\
\hline SE & $\begin{array}{c}146.579 .94 \\
1\end{array}$ & 42.430 .000 & 82.131 .908 & 0* & $\begin{array}{c}185.277 .44 \\
5\end{array}$ & $\begin{array}{c}142.503 .46 \\
6\end{array}$ \\
\hline $\begin{array}{l}\text { Centro } \\
\text {-Oeste }\end{array}$ & $\begin{array}{c}2.532 .344 .7 \\
21\end{array}$ & $\begin{array}{c}3.545 .758 .1 \\
26\end{array}$ & $\begin{array}{c}3.593 .232 .9 \\
89\end{array}$ & $\begin{array}{c}3.147 .254 .5 \\
88\end{array}$ & $\begin{array}{c}1.369 .420 .3 \\
71\end{array}$ & $\begin{array}{c}1.120 .854 .5 \\
07\end{array}$ \\
\hline DF & $\begin{array}{c}373.758 .02 \\
4\end{array}$ & 65.743 .609 & 7.276 .100 & $\begin{array}{c}143.461 .09 \\
0\end{array}$ & $\begin{array}{c}869.076 .66 \\
1\end{array}$ & $\begin{array}{c}403.266 .90 \\
3\end{array}$ \\
\hline $\mathrm{GO}$ & $\begin{array}{c}1.305 .839 .6 \\
16\end{array}$ & $\begin{array}{c}1.766 .503 .9 \\
80\end{array}$ & $\begin{array}{c}1.377 .299 .8 \\
89\end{array}$ & $\begin{array}{c}2.577 .448 .2 \\
23\end{array}$ & 16.868 .945 & $\begin{array}{c}530.912 .39 \\
6\end{array}$ \\
\hline MS & $\begin{array}{c}428.989 .75 \\
2\end{array}$ & $\begin{array}{c}1.341 .342 .8 \\
43\end{array}$ & $\begin{array}{c}2.183 .547 .0 \\
00\end{array}$ & 0* & 51.875 .000 & $\begin{array}{c}166.742 .73 \\
0\end{array}$ \\
\hline MT & $\begin{array}{c}423.757 .32 \\
8\end{array}$ & $\begin{array}{c}372.167 .69 \\
3\end{array}$ & 25.110 .000 & $\begin{array}{c}426.345 .27 \\
5\end{array}$ & $\begin{array}{c}431.599 .76 \\
5\end{array}$ & 19.932 .478 \\
\hline Sudeste & $\begin{array}{c}14.549 .322 \\
209\end{array}$ & $\begin{array}{c}12.041 .066 . \\
465\end{array}$ & $\begin{array}{c}13.156 .598 . \\
718\end{array}$ & $\begin{array}{c}4.331 .433 .2 \\
92\end{array}$ & $\begin{array}{c}12.240 .564 \\
558\end{array}$ & $\begin{array}{c}26.831 .744 \\
074\end{array}$ \\
\hline ES & $\begin{array}{c}184.014 .12 \\
5\end{array}$ & 46.368 .131 & 50.000 .000 & $\begin{array}{c}379.036 .23 \\
2\end{array}$ & $\begin{array}{c}123.065 .44 \\
5\end{array}$ & 35.119 .624 \\
\hline MG & $\begin{array}{c}1.431 .523 .8 \\
85\end{array}$ & $\begin{array}{c}786.349 .73 \\
4\end{array}$ & $\begin{array}{c}957.310 .46 \\
7\end{array}$ & $\begin{array}{c}216.225 .54 \\
9\end{array}$ & 32.500 .000 & $\begin{array}{c}360.810 .37 \\
7\end{array}$ \\
\hline RJ & $\begin{array}{c}10.484 .878 \\
568\end{array}$ & $\begin{array}{c}10.078 .655 \\
328\end{array}$ & $\begin{array}{c}11.113 .538 \\
251\end{array}$ & $\begin{array}{c}1.631 .763 .8 \\
63\end{array}$ & $\begin{array}{c}10.023 .927 \\
531\end{array}$ & $\begin{array}{c}26.083 .207 \\
254\end{array}$ \\
\hline SP & $\begin{array}{c}2.448 .905 .6 \\
29\end{array}$ & $\begin{array}{c}1.129 .693 .2 \\
72\end{array}$ & $\begin{array}{c}1.035 .750 .0 \\
00\end{array}$ & $\begin{array}{c}2.104 .407 .6 \\
48\end{array}$ & $\begin{array}{c}2.061 .071 .5 \\
81\end{array}$ & $\begin{array}{c}352.606 .81 \\
9\end{array}$ \\
\hline
\end{tabular}




\begin{tabular}{|c|c|c|c|c|c|c|}
\hline Sul & 1.490 .793 .8 & 980.491 .56 & 1.100 .220 .4 & 996.743 .02 & 448.104 .87 & 1.394 .112 .4 \\
& 12 & 6 & 60 & 5 & 7 & 65 \\
\hline PR & 182.150 .75 & 127.765 .40 & 330.700 .00 & 189.086 .75 & 177.254 .41 & 158.971 .25 \\
& 0 & 9 & 0 & 8 & 6 & 2 \\
\hline \multirow{2}{*}{ RS } & 930.685 .19 & 633.988 .50 & 656.073 .82 & 418.973 .82 & 218.975 .46 & 1.185 .231 .1 \\
& 4 & 5 & 8 & 8 & 1 & 86 \\
\hline \multirow{2}{*}{ SC } & 377.957 .86 & 218.737 .65 & 113.446 .63 & 388.682 .43 & 51.875 .000 & 49.910 .026 \\
\hline \multirow{2}{*}{ Total } & 86.760 .331$. & 38.311 .440$. & 34.713 .120$. & 12.387 .221$. & 20.481 .849$. & 34.717 .250$. \\
& 709 & 252 & 546 & 499 & 953 & 363 \\
\hline
\end{tabular}

* Os valores zerados referem-se a empreendimentos aportados por funcionais programáticas de anos anteriores e por isso não foram considerados no cálculo, segundo o Fiscobras.

Fonte: adaptado de BRASIL (2011); BRASIL (2012); BRASIL (2013); BRASIL (2014); BRASIL (2015); BRASIL (2016).

Esses valores são indicativos de concentração de obras públicas em unidades federativas específicas. Em alguns estados a explicação é lógica, pois concentram as cidades mais populosas do Brasil, ou realização de algum evento específico como as Olimpíadas 2016 no Rio de Janeiro, mas em outros estados não, como no caso de Pernambuco frente ao restante do Nordeste. Portanto, a metodologia de amostragem das obras públicas a serem fiscalizadas pelo TCU não é bem clara e deveria ser melhor demonstrada nos relatórios Fiscobras para se evitar favorecimentos e mascaramentos da real situação das obras públicas no Brasil.

$\mathrm{Na}$ tentativa de encontrar uma lógica entre as obras públicas e as fiscalizações realizadas pelo TCU utilizou-se o Índice de Desenvolvimento Humano Municipal (IDH-M) de 2010 (PNUD, 2016), pois há relação direta entre o índice e a necessidade de serviços públicos pela população (Tabela 3). Houve alguns indícios de acerto, como por exemplo em relação ao Nordeste que possui o menor IDH-M do Brasil $(0,663)$, no entanto, o Norte onde o valor é quase idêntico $(0,667)$ não há tantas obras ou dotações orçamentárias fiscalizadas, havendo a mesma tendência em relação aos estados. Como sugestão o IDH-M poderia fazer parte da metodologia de escolha das fiscalizações de obras públicas pelo TCU no Brasil.

Tabela 3 - Índice de Desenvolvimento Humano Municipal (IDH-M) por Unidade Federativa no Brasil em 2010 (PNUD, 2016)

\begin{tabular}{|c|c|c|c|c|c|}
\hline Ranking & $\begin{array}{c}\text { Unidade da } \\
\text { Federação }\end{array}$ & IDH-M & $\begin{array}{c}\text { IDH-M } \\
\text { Renda }\end{array}$ & $\begin{array}{c}\text { IDH-M } \\
\text { Longevidade }\end{array}$ & $\begin{array}{c}\text { IDH-M } \\
\text { Educação }\end{array}$ \\
\hline $1 \cong$ & Distrito Federal & 0,824 & 0,863 & 0,873 & 0,742 \\
\hline $2 \varrho$ & São Paulo & 0,783 & 0,789 & 0,845 & 0,719 \\
\hline $3 \varrho$ & Santa Catarina & 0,774 & 0,773 & 0,860 & 0,697 \\
\hline $4 \subseteq$ & Rio de Janeiro & 0,761 & 0,782 & 0,835 & 0,675 \\
\hline
\end{tabular}




\begin{tabular}{|c|c|c|c|c|c|}
\hline 5 은 & Paraná & 0,749 & 0,757 & 0,830 & 0,668 \\
\hline 60 & Rio Grande do Sul & 0,746 & 0,769 & 0,840 & 0,642 \\
\hline 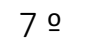 & Espírito Santo & 0,740 & 0,743 & 0,835 & 0,653 \\
\hline 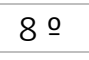 & Goiás & 0,735 & 0,742 & 0,827 & 0,646 \\
\hline 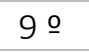 & Minas Gerais & 0,731 & 0,730 & 0,838 & 0,638 \\
\hline 10 ㅇ & Mato Grosso do Sul & 0,729 & 0,740 & 0,833 & 0,629 \\
\hline 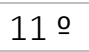 & Mato Grosso & 0,725 & 0,732 & 0,821 & 0,635 \\
\hline 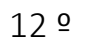 & Amapá & 0,708 & 0,694 & 0,813 & 0,629 \\
\hline 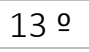 & Roraima & 0,707 & 0,695 & 0,809 & 0,628 \\
\hline $14 \stackrel{\circ}{\circ}$ & Tocantins & 0,699 & 0,690 & 0,793 & 0,624 \\
\hline 15 ㅇ & Rondônia & 0,690 & 0,712 & 0,800 & 0,577 \\
\hline 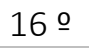 & Rio Grande do Norte & 0,684 & 0,678 & 0,792 & 0,597 \\
\hline 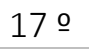 & Ceará & 0,682 & 0,651 & 0,793 & 0,615 \\
\hline $18 \stackrel{\circ}{0}$ & Amazonas & 0,674 & 0,677 & 0,805 & 0,561 \\
\hline 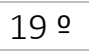 & Pernambuco & 0,673 & 0,673 & 0,789 & 0,574 \\
\hline 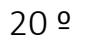 & Sergipe & 0,665 & 0,672 & 0,781 & 0,560 \\
\hline $21 \stackrel{0}{2}$ & Acre & 0,663 & 0,671 & 0,777 & 0,559 \\
\hline 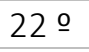 & Bahia & 0,660 & 0,663 & 0,783 & 0,555 \\
\hline 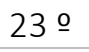 & Paraíba & 0,658 & 0,656 & 0,783 & 0,555 \\
\hline $24 \stackrel{0}{2}$ & Piauí & 0,646 & 0,635 & 0,777 & 0,547 \\
\hline 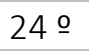 & Pará & 0,646 & 0,646 & 0,789 & 0,528 \\
\hline 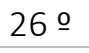 & Maranhão & 0,639 & 0,612 & 0,757 & 0,562 \\
\hline $27 \stackrel{\circ}{2}$ & Alagoas & 0,631 & 0,641 & 0,755 & 0,520 \\
\hline
\end{tabular}

Outro indicativo bem interessante dos relatórios Fiscobras é a escolha das fiscalizações por setores estratégicos, ou pela natureza da obra, sendo que essa separação fornece indicativos mais contundentes da gestão estratégica da governança brasileira. O setor de logística/transportes foi o mais fiscalizado em todos os anos analisados (Tabela 4).

Tabela 4 - Distribuição percentual das fiscalizações por tipo de obra (setor ou natureza) do Fiscobras no Brasil

\begin{tabular}{|c|c|c|c|c|c|c|}
\hline Tipo de Obra (setor) & 2011 & 2012 & 2013 & 2014 & 2015 & 2016 \\
\hline Energia & 9,13 & 15,50 & 8,10 & 4,90 & 7,22 & 23,02 \\
\hline Hidrelétrica & 1,74 & 0,50 & 0,74 & 1,96 & 2,06 & 5,56 \\
\hline Elétrica & 1,30 & 9,00 & 0,00 & 0,98 & 1,03 & 10,31 \\
\hline Usina Termelétrica & 0,43 & 1,00 & 0,74 & 0,00 & 1,03 & 0,79 \\
\hline Obras Especiais & 5,65 & 5,00 & 6,62 & 1,96 & 3,09 & 6,35 \\
\hline Transportes & 50,87 & 52,50 & 56,62 & 54,90 & 21,65 & 39,68 \\
\hline Aeroporto & 4,35 & 6,50 & 12,50 & 10,78 & 4,12 & 4,76 \\
\hline Dragagem e Derrocamento & 1,74 & 0,50 & 0,00 & 0,98 & 3,09 & 0,79 \\
\hline Infraestrutura Portuária & 0,87 & 0,50 & 0,74 & 1,96 & 1,03 & 0,00 \\
\hline Pontes e Viadutos & 17,83 & 1,00 & 1,47 & 1,96 & 0,00 & 0,79 \\
\hline Porto & 1,30 & 12,00 & 6,62 & 4,90 & 2,06 & 5,56 \\
\hline Rodovia - Construção ou Implantação & 7,83 & 9,00 & 9,56 & 7,84 & 2,06 & 5,56 \\
\hline
\end{tabular}




\begin{tabular}{|c|c|c|c|c|c|c|}
\hline Rodovia - Duplicação & 8,26 & 6,50 & 12,50 & 1,96 & 3,09 & 3,97 \\
\hline Rodovia - Manutenção & 0,87 & 4,00 & 1,47 & 9,80 & 2,06 & 11,90 \\
\hline Rodovia - Restauração ou Recuperação & 1,30 & 6,50 & 2,21 & 0,98 & 1,03 & 1,59 \\
\hline Ferrovia Metropolitana e Trem Urbano & 6,52 & 6,00 & 9,56 & 13,73 & 3,09 & 4,76 \\
\hline Obras Hídricas & 7,83 & 8,00 & 16,17 & 9,80 & 3,09 & 4,76 \\
\hline Adutora & 1,30 & 1,50 & 4,40 & 2,94 & 0,00 & 0,79 \\
\hline Barragem/Açude & 2,61 & 2,50 & 2,21 & 1,96 & 1,03 & 0,79 \\
\hline Canal & 2,17 & 2,50 & 9,56 & 4,90 & 2,06 & 2,38 \\
\hline Irrigação & 1,74 & 1,50 & 0,00 & 0,00 & 0,00 & 0,79 \\
\hline Edificações & 16,09 & 14,00 & 11,03 & 25,49 & 16,49 & 11,90 \\
\hline Administrativos & 4,78 & 3,50 & 2,21 & 0,98 & 3,09 & 0,79 \\
\hline Escolas & 0,87 & 7,50 & 4,41 & 8,82 & 0,00 & 0,79 \\
\hline Hospitais & 0,87 & 2,50 & 1,47 & 11,77 & 5,15 & 3,97 \\
\hline Esportes & 0,00 & 0,00 & 0,00 & 2,94 & 3,09 & 2,38 \\
\hline Outros Edifícios & 9,57 & 0,50 & 2,94 & 0,98 & 5,15 & 3,96 \\
\hline Infraestrutura Urbana & 16,09 & 10,00 & 8,08 & 4,90 & 51,55 & 20,63 \\
\hline Total & 100 & 100 & 100 & 100 & 100 & 100 \\
\hline
\end{tabular}

Fonte: adaptado de BRASIL (2011); BRASIL (2012); BRASIL (2013); BRASIL (2014); BRASIL (2015); BRASIL (2016).

Nos últimos dois anos (2015 e 2016), as fiscalizações aumentaram para o setor de energia e infraestrutura urbana (Tabela 4), sobretudo mobilidade urbana, e isso se justifica em detrimento das dotações orçamentárias dispendidas nestes setores (Tabela 5). Como obras destaques pode-se citar a Usina de Belo Monte no Pará, Refinaria de Abreu e Lima em Pernambuco, Complexo Petroquímico do Rio de Janeiro (obras especiais de energia), linhas do metrô em São Paulo.

Tabela 5 - Distribuição percentual das dotações orçamentárias por tipo de obra (setor ou natureza) do Fiscobras no Brasil

\begin{tabular}{|c|c|c|c|c|c|c|}
\hline Tipo de Obra (setor) & 2011 & 2012 & 2013 & 2014 & 2015 & 2016 \\
\hline Energia & 63,74 & 62,26 & 68,25 & 5,22 & 52,29 & 80,73 \\
\hline Hidrelétrica & 1,77 & 0,21 & 0,38 & 0,00 & 16,48 & 12,23 \\
\hline Elétrica & 0,42 & 3,56 & 0,00 & 5,22 & 1,52 & 3,94 \\
\hline Usina Termétrica & 0,64 & 1,49 & 0,81 & 0,00 & 0,98 & 0,65 \\
\hline Obras Especiais & 60,90 & 57,00 & 67,07 & 0,00 & 33,31 & 63,91 \\
\hline Transportes & 26,30 & 22,45 & 13,70 & 20,76 & 14,45 & 7,88 \\
\hline Aeroporto & 2,06 & 3,74 & 2,23 & 8,11 & 2,10 & 1,04 \\
\hline Dragagem e Derrocamento & 0,13 & 0,00 & 0,00 & 0,01 & 1,14 & 0,17 \\
\hline Infraestrutura Portuária & 0,22 & 0,00 & 0,00 & 0,00 & 0,48 & 0,00 \\
\hline Pontes e Viadutos & 6,38 & 0,20 & 0,09 & 0,60 & 0,00 & 0,19 \\
\hline Porto & 0,22 & 0,28 & 0,21 & 0,34 & 0,38 & 1,11 \\
\hline Rodovia - Construção ou Implantação & 4,77 & 4,45 & 2,61 & 1,99 & 0,33 & 0,72 \\
\hline Rodovia - Duplicação & 5,62 & 4,74 & 4,27 & 0,16 & 1,07 & 0,37 \\
\hline Rodovia - Manutenção & 0,23 & 1,65 & 0,74 & 0,00 & 1,77 & 1,97 \\
\hline
\end{tabular}




\begin{tabular}{|c|c|c|c|c|c|c|}
\hline Rodovia - Restauração ou Recuperação & 0,18 & 1,95 & 0,00 & 0,00 & 1,35 & 0,10 \\
\hline Ferrovia Metropolitano e Trem Urbano & 6,50 & 5,44 & 3,53 & 9,54 & 5,84 & 2,21 \\
\hline Obras Hídricas & 4,33 & 4,72 & 4,92 & 6,82 & 2,42 & 4,27 \\
\hline Adutora & 0,39 & 0,77 & 0,00 & 1,63 & 0,00 & 0,90 \\
\hline Barragem/Açude & 0,13 & 0,57 & 0,00 & 0,41 & 0,26 & 0,00 \\
\hline Canal & 3,38 & 3,33 & 4,92 & 4,78 & 2,15 & 3,86 \\
\hline Irrigação & 0,43 & 0,04 & 0,00 & 0,00 & 0,00 & 0,22 \\
\hline Edificações & 3,55 & 5,13 & 12,38 & 65,23 & 3,50 & 4,78 \\
\hline Administrativos & 2,66 & 1,53 & 3,01 & 0,36 & 0,67 & 0,07 \\
\hline Escolas & 0,00 & 2,78 & 5,72 & 41,57 & 0,00 & 0,29 \\
\hline Hospitais & 0,05 & 0,15 & 2,16 & 16,42 & 1,03 & 1,75 \\
\hline Esportes & 0,00 & 0,00 & 0,00 & 5,22 & 1,15 & 1,50 \\
\hline Outros Edifícios & 0,84 & 0,67 & 1,49 & 1,66 & 0,65 & 1,14 \\
\hline Infraestrutura Urbana & 2,08 & 5,45 & 0,75 & 1,97 & 27,34 & 2,33 \\
\hline Total & 100 & 100 & 100 & 100 & 100 & 100 \\
\hline
\end{tabular}

Fonte: adaptado de BRASIL (2011); BRASIL (2012); BRASIL (2013); BRASIL (2014); BRASIL (2015); BRASIL (2016).

Depois de visualizadas quais obras públicas foram objetos de fiscalização por parte do TCU, passa-se agora a demonstrar as irregularidades existentes. Até 2002 a LDO não trazia conceituação das irregularidades que ensejavam a recomendação de paralisação de obras, a LDO de 2003 exigiu que elas fossem materialmente relevantes. Por sua vez, a LDO de 2010 passou a requerer que o dano fosse materialmente relevante em relação ao valor contratado, chamada materialidade relativa. A LDO de 2012 impôs nova restrição, dessa vez em qualidade processual, ao definir como irregularidades graves apenas aquelas que foram objeto de deliberação por parte do TCU, ainda que de forma preliminar (BRASIL, 2015). Por isso, as irregularidades contidas nas obras públicas são classificadas em níveis hierárquicos de acordo com a gravidade, que demandam diferentes ações por parte do poder público e dos particulares:

IGP - Indício de irregularidade grave com recomendação de paralisação: atos e fatos que, sendo materialmente relevantes em relação ao valor total contratado, apresentem potencialidade de ocasionar prejuízos ao erário ou a terceiros, e que possam ensejar nulidade de procedimento licitatório ou de contrato, ou configurem graves desvios relativamente aos princípios constitucionais a que está submetida a administração pública federal;

IGR - Indício de irregularidade grave com retenção parcial de valores: aquele que, embora atenda à conceituação contida no IGP, permite a continuidade da obra desde que haja autorização do contratado para retenção de valores a serem pagos, ou a apresentação de garantias suficientes para prevenir o possível dano ao erário, até a decisão de mérito sobre o indício relatado; 
IGC - Indício de irregularidade grave que não prejudique a continuidade: aquele que, embora gere citação ou audiência do responsável, não atende à conceituação de IGP ou IGR;

Falhas/Impropriedades: falhas de natureza formal ou outras impropriedades que não configurem indício de débito ou que não ensejem a aplicação de multa aos responsáveis, mas tão somente determinação de medidas corretivas ou expedição de ciência;

Sem ressalva: caso a fiscalização não tenha resultado em qualquer achado (BRASIL, 2016b).

A tendência ao longo do tempo das irregularidades nas obras públicas no Brasil foi de estabilidade (Tabela 6). No entanto, a situação é preocupante, pois, em média, $65 \%$ das obras públicas apresentaram irregularidades graves e apenas $8 \%$ não apresentaram problemas no País. Tal situação desmitifica algumas afirmações propostas por Ribeiro (2012), de que o modelo de gerenciamento intensivo adotado pelo Poder Executivo para as obras incluídas no PAC, aliada à garantia de liberação de recursos financeiros para os empreendimentos, constituem-se em instrumentos poderosos para a celeridade na execução dos serviços contratados e para a superação de entraves.

Tabela 6 - Distribuição percentual das fiscalizações de obras públicas em função do indício de maior gravidade do Fiscobras no Brasil

\begin{tabular}{|c|c|c|c|c|c|c|}
\hline Indício & 2011 & 2012 & 2013 & 2014 & 2015 & 2016 \\
\hline Irregularidades graves & 82,6 & 62,0 & 61,7 & 56,9 & 62,9 & 61,1 \\
\hline IGP* & 13,5 & 11,0 & 5,1 & 4,0 & 5,2 & 11,9 \\
\hline IGR* & 3,0 & 3,0 & 5,9 & 4,9 & 4,1 & 0,8 \\
\hline IGC* & 66,1 & 48,0 & 50,7 & 48,0 & 53,6 & 48,4 \\
\hline Falhas/Impropriedades & 13,9 & 33,5 & 20,7 & 38,2 & 29,9 & 30,2 \\
\hline Sem Ressalva & 3,5 & 4,50 & 17,6 & 4,9 & 7,2 & 8,7 \\
\hline
\end{tabular}

*IGP - Indício de irregularidade grave com recomendação de paralisação; IGR - Indício de irregularidade grave com retenção parcial de valores; IGC - Indício de irregularidade grave que não prejudique a continuidade.

Fonte: adaptado de BRASIL (2011); BRASIL (2012); BRASIL (2013); BRASIL (2014); BRASIL (2015); BRASIL (2016).

A média das obras fiscalizadas com IGP (Indício de irregularidade grave com recomendação de paralisação) foi de $8,45 \%$ no período analisado. Tais resultados colocam em dúvida as afirmações de Ribeiro (2012) de que a atual sistemática de fiscalização de obras, que envolve o planejamento e a articulação da Comissão Mista de Planos, Orçamentos Públicos e Fiscalização (CMO) com o TCU e os órgãos gestores, vem se mostrando bastante eficaz para prevenir prejuízos ao erário, visto que essa classificação (IGP) ocorre quando já estão constatados prejuízos ao erário. 
Vários são os mecanismos de controle, previstos nas legislações (Lei № 8.666/93 e Lei no 12.462/11) e em outras normas, das obras públicas no Brasil, durante todas as fases das licitações, inclusive anteriormente a elas para se evitar as irregularidades graves:

Art. 27. Para a habilitação nas licitações exigir-se-á dos interessados, exclusivamente, documentação relativa a:

I - habilitação jurídica;

II - qualificação técnica;

III - qualificação econômico-financeira;

IV - regularidade fiscal;

V - cumprimento do disposto no inciso XXXIII do art. $7^{\circ}$ da Constituição Federal (BRASIL, 1993).

Art. 67. A execução do contrato deverá ser acompanhada e fiscalizada por um representante da Administração especialmente designado, permitida a contratação de terceiros para assisti-lo e subsidiá-lo de informações pertinentes a essa atribuição.

$\S 1$ O O representante da Administração anotará em registro próprio todas as ocorrências relacionadas com a execução do contrato, determinando o que for necessário à regularização das faltas ou defeitos observados.

$\S 2^{\circ}$ As decisões e providências que ultrapassarem a competência do representante deverão ser solicitadas a seus superiores em tempo hábil para a adoção das medidas convenientes (BRASIL, 1993).

Um mecanismo de controle criado pelo RDC, tido como destaque foi o sistema de registro de preços, que consiste em um procedimento administrativo para levantar formalmente os preços e condições para celebrar futuramente outros contratos administrativos.

Art. 32. O Sistema de Registro de Preços, especificamente destinado às licitações de que trata esta lei, reger-se-á pelo disposto em regulamento. $\S 1$ o Poderá aderir ao sistema referido no caput deste artigo qualquer órgão ou entidade responsável pela execução das atividades contempladas no art. 1 o desta lei.

$\S 2$ O O registro de preços observará, entre outras, as seguintes condições: I - efetivação prévia de ampla pesquisa de mercado;

II - seleção de acordo com os procedimentos previstos em regulamento;

III - desenvolvimento obrigatório de rotina de controle e atualização periódicos dos preços registrados;

IV - definição da validade do registro; e

$\checkmark$ - inclusão, na respectiva ata, do registro dos licitantes que aceitarem cotar os bens ou serviços com preços iguais ao do licitante vencedor na sequência da classificação do certame, assim como dos licitantes que mantiverem suas propostas originais.

$\S 3$ ㅇ A existência de preços registrados não obriga a administração pública a firmar os contratos que deles poderão advir, sendo facultada a realização de licitação específica, assegurada ao licitante registrado preferência em igualdade de condições.

Esse mecanismo foi criado no intuito de suprimir principalmente sobrepreço e superfaturamento de obras públicas no Brasil, irregularidades recorrentes no País. No entanto, 
parece que tais mecanismos de controle estão sendo utilizados da forma incorreta ou então burlados de alguma forma, pois em média, 8,45\% das obras públicas apresentaram irregularidade gravíssima IGP, que estabelece imediata paralisação da obra, pois está causando elevado dano ao erário.

Para Ribeiro (2012), as crônicas deficiências do planejamento público, que levam à contratação de obras com projetos desatualizados ou elaborados às pressas, apenas para não perder os recursos orçamentários explicam os elevados índices de irregularidades nessa área governamental.

Em função disso, é imperativo compreender em que fases ou áreas das obras públicas estão ocorrendo os principais problemas. O Fiscobras contabiliza tal problema por meio dos achados, que são circunstâncias em que ocorrem problemas durante as fiscalizações (Tabela 7). Houveram muitos achados na execução da obra. Normalmente esta fase é onde ocorrem mais problemas e uma mesma obra pode apresentar muitos achados. Por isso é importante considerar as fiscalizações com achados, por exemplo, 24,3\% das fiscalizações com achados ocorreram na fase de execução da obra.

Tabela 7 - Distribuição unitária e percentual médios dos achados e fiscalizações de obras públicas em função da área de ocorrência do Fiscobras no Brasil

\begin{tabular}{|c|c|c|c|}
\hline Área de ocorrência & $\begin{array}{c}\text { Achados } \\
\text { (unidade) }\end{array}$ & $\begin{array}{c}\text { Fiscalizações } \\
\text { (unidade) }\end{array}$ & $\begin{array}{c}\text { Fiscalizações com achados* } \\
\text { (\%) }\end{array}$ \\
\hline Processo licitatório & 107,0 & 70,6 & 36,4 \\
\hline Projeto básico ou executivo & 109,3 & 67,6 & 35,3 \\
\hline Sobrepreço/superfaturamento & 93,0 & 57,6 & 29,3 \\
\hline Formalização do consórcio & 64,0 & 30,4 & 16,9 \\
\hline Fiscalização da obra & 64,0 & 30,6 & 16,1 \\
\hline Execução da obra & 124,5 & 35,2 & 24,3 \\
\hline Formalização e execução do contrato & 59,0 & 17,2 & 16,7 \\
\hline Dotação orçamentária & 19,7 & 12,0 & 5,8 \\
\hline Descumprimento/obstrução & 18,3 & 10,8 & 6,0 \\
\hline Meio Ambiente & 9,8 & 3,8 & 2,4 \\
\hline
\end{tabular}

*A porcentagem de fiscalizações com achados não resulta em $100 \%$ pois uma mesma obra pode ter irregularidades em diversas áreas de ocorrência.

Fonte: adaptado de BRASIL (2011); BRASIL (2012); BRASIL (2013); BRASIL (2014); BRASIL (2015); BRASIL (2016).

Em média, as áreas em que mais ocorreram irregularidades foram no processo licitatório, seguido do projeto básico ou executivo. Essas fases são anteriores à execução propriamente dita da obra, por isso podem revelar problemas do gestor público no 
planejamento licitatório. Outras áreas que mereceram destaque negativo foram sobrepreço/superfaturamento e execução da obra, que podem indicar problemas com o contratado.

No entanto, as áreas em que mais ocorreram irregularidades oscilam entre os anos, podendo ser indicativo de que o RDC possa ter alterado a fase ou área de ocorrência das irregularidades das obras públicas no Brasil (Tabela 8).

\section{Tabela 8 - Distribuição unitária e percentual dos achados e fiscalizações de obras públicas em função da área de ocorrência do Fiscobras no Brasil, entre 2011 e 2016}

\begin{tabular}{|c|c|c|c|c|c|c|c|}
\hline & $\begin{array}{l}\text { Achados } \\
\text { (unidade) }\end{array}$ & $\begin{array}{c}\text { Fiscalizações } \\
\text { (unidade) }\end{array}$ & $\begin{array}{c}\text { Fiscalizações } \\
\text { c/ achados* } \\
(\%)\end{array}$ & $\begin{array}{l}\text { Achados } \\
\text { (unidade) }\end{array}$ & $\begin{array}{c}\text { Fiscalizações } \\
\text { (unidade) }\end{array}$ & $\begin{array}{c}\text { Fiscalizações } \\
\text { c/achados* } \\
(\%)\end{array}$ & \\
\hline Área de ocorrência & \multicolumn{6}{|c|}{2011} & 2012 \\
\hline Processo licitatório & 215 & 168 & 73,0 & 146 & 78 & 39,0 & \\
\hline Projeto básico ou executivo & 178 & 142 & 62,0 & 141 & 98 & 49,0 & \\
\hline Sobrepreço/superfaturamento & 230 & 126 & 56,0 & 154 & 92 & 46,0 & \\
\hline Formalização do consórcio & 76 & 54 & 23,0 & 58 & 37 & 18,5 & \\
\hline Fiscalização da obra & 76 & 50 & 22,0 & 97 & 46 & 23,0 & \\
\hline Execução da obra & 78 & 40 & 17,0 & 69 & 33 & 16,5 & \\
\hline $\begin{array}{l}\text { Formalização e execução do } \\
\text { contrato }\end{array}$ & 67 & 38 & 17,0 & 11 & 10 & 5,0 & \\
\hline Dotação orçamentária & 56 & 29 & 13,0 & 21 & 17 & 8,5 & \\
\hline Descumprimento/obstrução & 48 & 22 & 10,0 & 10 & 7 & 3,5 & \\
\hline Meio Ambiente & 16 & 8 & 3,0 & 7 & 3 & 1,5 & \\
\hline Área de ocorrência & \multicolumn{6}{|c|}{2013} & 2014 \\
\hline Processo licitatório & 90 & 48 & 35,3 & 37 & 18 & 17,6 & \\
\hline Projeto básico ou executivo & 58 & 32 & 23,5 & 173 & 35 & 34,3 & \\
\hline Sobrepreço/superfaturamento & 55 & 40 & 29,4 & 11 & 9 & 8,8 & \\
\hline Formalização consórcio & 36 & 21 & 15,4 & 95 & 15 & 14,7 & \\
\hline Fiscalização da obra & 71 & 24 & 17,6 & 105 & 21 & 20,6 & \\
\hline Execução da obra & 24 & 18 & 13,2 & 362 & 42 & 41,2 & \\
\hline $\begin{array}{l}\text { Formalização e execução do } \\
\text { contrato }\end{array}$ & 13 & 6 & 4,4 & 33 & 20 & 19,6 & \\
\hline Dotação orçamentária & 4 & 4 & 2,9 & 4 & 4 & 3,9 & \\
\hline Descumprimento/obstrução & 21 & 13 & 9,6 & 10 & 6 & 5,9 & \\
\hline Meio Ambiente & 9 & 1 & 0,7 & 10 & 3 & 2,9 & \\
\hline Área de ocorrência & \multicolumn{6}{|c|}{2015} & 2016 \\
\hline Processo licitatório & 95 & 41 & 42,3 & 59 & $* *$ & 11,4 & \\
\hline Projeto básico ou executivo & 51 & 31 & 32,0 & 55 & $* *$ & 11,0 & \\
\hline Sobrepreço/superfaturamento & 39 & 21 & 21,6 & 69 & $* *$ & 13,7 & \\
\hline Formalização consórcio & 98 & 25 & 25,8 & 21 & $* *$ & 4,2 & \\
\hline Fiscalização da obra & 31 & 12 & 12,4 & 4 & $* *$ & 0,8 & \\
\hline
\end{tabular}




\begin{tabular}{|c|c|c|c|c|c|c|}
\hline Execução da obra & 148 & 43 & 44,3 & 66 & $* *$ & 13,5 \\
\hline $\begin{array}{c}\text { Formalização e execução do } \\
\text { contrato }\end{array}$ & 21 & 12 & 12,4 & 209 & $* *$ & 41,6 \\
\hline Dotação orçamentária & 31 & 6 & 6,2 & 2 & $* *$ & 0,4 \\
\hline Descumprimento/obstrução & 16 & 6 & 6,2 & 5 & $* *$ & 1,0 \\
\hline Meio Ambiente & 5 & 4 & 4,1 & 12 & $* *$ & 2,4 \\
\hline
\end{tabular}

*A porcentagem de fiscalizações com achados não resulta em $100 \%$ pois uma mesma obra pode ter irregularidades em diversas áreas de ocorrência.

**A metodologia para adequação das fiscalizações às áreas de ocorrência mudou, por isso não há dados referentes às fiscalizações neste ano.

Fonte: adaptado de BRASIL (2011); BRASIL (2012); BRASIL (2013); BRASIL (2014); BRASIL (2015); BRASIL (2016).

Uma questão primordial defendida por muitos autores (CELESTINO, 2012; RIBEIRO, 2012), inclusive pelo Governo Federal (BRASIL, 2016b), é a supremacia do RDC em relação à Lei no 8.666/93, sobretudo para evitar paralisações e irregularidades nas grandes obras públicas no âmbito da União. Somente foi possível realizar essa relação a partir de 2014, visto que a Lei № 12.462/11 que instituiu o RDC foi promulgada em 2011, levando certo período de tempo até uma grande obra pública ser licitada nesse novo regime e auditada no ano seguinte pelo TCU. No entanto, não houve diferença entre o regime licitatório proporcionado pelo RDC em relação ao regime estabelecido pela Lei № 8.666/93 para diminuir irregularidades de quaisquer tipos nas grandes obras públicas no Brasil, nos três anos analisados (Tabela 9).

Tabela 9 - Distribuição percentual dos indícios de irregularidades em obras públicas entre a Lei no 8.666/93 e o Regime Diferencial de Contratação (RDC) do Fiscobras no Brasil

\begin{tabular}{|c|c|c|c|c|c|c|}
\hline \multirow{2}{*}{ Indício } & \multicolumn{2}{|c|}{2014} & \multicolumn{2}{c|}{2015} & 2016 \\
\hline & Lei 8666/93 & RDC & Lei 8666/93 & RDC & Lei 8666/93 & RDC \\
\hline IGP* & 4,1 & 3,5 & 2,7 & 13,6 & 13,0 & 10,2 \\
\hline IGR* & 6,8 & 0,0 & 4,0 & 4,5 & 1,3 & 0,0 \\
\hline IGC* & 51,4 & 39,3 & 57,3 & 40,9 & 46,8 & 51,0 \\
\hline Falhas/Impropriedades & 35,1 & 46,4 & 30,7 & 27,3 & 28,6 & 32,7 \\
\hline Sem Ressalva & 2,7 & 10,7 & 5,3 & 13,6 & 10,4 & 6,1 \\
\hline
\end{tabular}

*IGP - Indício de irregularidade grave com recomendação de paralisação; IGR - Indício de irregularidade grave com retenção parcial de valores; IGC - Indício de irregularidade grave que não prejudique a continuidade.

Fonte: adaptado de BRASIL (2014); BRASIL (2015); BRASIL (2016). 
Atualmente a Lei no 12.462/2011 está em vigência, mas é objeto de duas Ações Diretas de Inconstitucionalidade - ADI's no 4.645 e no $4.655 / 11^{4}$ conexas, cujos conteúdos discutem aspectos formais e materiais da Lei (BRASIL, 2011c). O sistema referencial de custos em que as obras deveriam se basear, instituído pelo art. 71 da Lei no 9.811/99 (LDO 2000), foi sacramentado no RDC para a fase executiva da obra, sendo que sobretudo a Administração Pública deveria obedecer esse sistema na elaboração do projeto básico. No entanto, o Ministério Público Federal alega que o principal problema no aspecto material da lei reside no modelo de contratação integrada, que permite a concentração do projeto básico, projeto executivo e execução da obra em um mesmo contratante, flexibilizando a obediência ao sistema referencial de custos (BRASIL, 2011c).

Art. 8 $\mathrm{Na}$ execução indireta de obras e serviços de engenharia, são admitidos os seguintes regimes: [...]

$\checkmark$ - contratação integrada. [...]

$\S 3$ O O custo global de obras e serviços de engenharia deverá ser obtido a partir de custos unitários de insumos ou serviços menores ou iguais à mediana de seus correspondentes ao Sistema Nacional de Pesquisa de Custos e Índices da Construção Civil (Sinapi), no caso de construção civil em geral, ou na tabela do Sistema de Custos de Obras Rodoviárias (Sicro), no caso de obras e serviços rodoviários.

$\S 4$ ํ No caso de inviabilidade da definição dos custos consoante o disposto no $\S 3^{\circ}$ - deste artigo, a estimativa de custo global poderá ser apurada por meio da utilização de dados contidos em tabela de referência formalmente aprovada por órgãos ou entidades da administração pública federal, em publicações técnicas especializadas, em sistema específico instituído para o setor ou em pesquisa de mercado.

§ 5o Nas licitações para a contratação de obras e serviços, com exceção daquelas onde for adotado o regime previsto no inciso $\mathrm{V}$ do caput deste artigo, deverá haver projeto básico aprovado pela autoridade competente, disponível para exame dos interessados em participar do processo licitatório.

Art. 9o Nas licitações de obras e serviços de engenharia, no âmbito do RDC, poderá ser utilizada a contratação integrada, desde que técnica e economicamente justificada e cujo objeto envolva, pelo menos, uma das seguintes condições:

I - inovação tecnológica ou técnica;

II - possibilidade de execução com diferentes metodologias; ou

III - possibilidade de execução com tecnologias de domínio restrito no mercado.

\footnotetext{
${ }^{4}$ Ministro relator das duas ações, Luiz Fux, no Supremo Tribunal Federal, que se manifestou no sentido de que a matéria reveste-se de indiscutível relevância e especial significado para a ordem social e a segurança jurídica, razão pela qual determinou a adoção de rito mais célere, no entanto, encontra-se conclusa desde 12/03/2013, e dependendo de julgamento até a presente data. Disponível em: $<$ http://www.stf.jus.br/portal/processo/verProcessoAndamento.asp?incidente $=4138546>$. Acesso em 01 jun. 2017.
} 
$\S 1$ 1ํ A contratação integrada compreende a elaboração e o desenvolvimento dos projetos básico e executivo, a execução de obras e serviços de engenharia, a montagem, a realização de testes, a préoperação e todas as demais operações necessárias e suficientes para a entrega final do objeto.

$\S 2$ 응 No caso de contratação integrada: [...]

II - o valor estimado da contratação será calculado com base nos valores praticados pelo mercado, nos valores pagos pela administração pública em serviços e obras similares ou na avaliação do custo global da obra, aferida mediante orçamento sintético ou metodologia expedita ou paramétrica.

$\S 40$ Nas hipóteses em que for adotada a contratação integrada, é vedada a celebração de termos aditivos aos contratos firmados, exceto nos seguintes casos:

I - para recomposição do equilíbrio econômico-financeiro decorrente de caso fortuito ou força maior; e

II - por necessidade de alteração do projeto ou das especificações para melhor adequação técnica aos objetivos da contratação, a pedido da administração pública, desde que não decorrentes de erros ou omissões por parte do contratado, observados os limites previstos no $\S 1$ 을 do art. 65 da Lei no 8.666, de 21 de junho de 1993 (BRASIL, 2011b).

Essa flexibilização desvirtuaria os princípios e propósitos da licitação, em especial a ampla competividade, uma vez que o objeto não foi definido de forma clara, pois o RDC tornou facultativa a utilização dos atuais sistemas referenciais de custos, de utilização obrigatória pela Administração Pública para contratação da execução indireta de obras e serviços de engenharia (BRASIL, 2011c). Esse fato corrobora com as proposições citadas anteriormente sobre o possível logro ao sistema de Registro de Preços. Segundo Ribeiro (2012), quando há concentração, inclusive do projeto básico, em um mesmo contratante pode ser que os orçamentos elaborados para orientar o processo licitatório estejam sujeitos a maior grau de imprecisão, por estarem embasados em estudos técnicos e anteprojetos elaborados de forma sintética, expedita ou parametrizada. Orçamentos elaborados nessas condições podem levar à definição imprecisa de insumos, serviços e técnicas a serem utilizados, trazendo insegurança aos interessados em participar do certame e aumentam a possibilidade de conflitos com a Administração Pública. Segundo esse autor, a imprecisão ocasiona o dimensionamento incorreto do orçamento, situação invariavelmente danosa ao Estado. A superestimativa normalmente acarreta sobrepreço e superfaturamento, enquanto a subestimativa o desequilíbrio econômicofinanceiro dos contratos, ocasionando atrasos, paralisações e dificuldades de cumprimento do contrato por parte do licitante vencedor. Ribeiro (2012) tem razão em parte, pois comparando o primeiro triênio (2011-2013) com o segundo (2014-2016) (Tabela 8), considerando que no primeiro não houve contratação de obras públicas via RDC, verificou-se que o primeiro triênio 
teve porcentagem maior de fiscalizações com achados referentes ao sobrepreço/superfaturamento, e menor porcentagem em relação à execução das obras, e formalização e execução dos contratos.

\section{CONSEQÛENCIAS DA INEXECUÇÃO TOTAL OU PARCIAL DE OBRAS PÚBLICAS NO BRASIL}

O sistema normativo licitatório brasileiro, sobretudo as leis que definiram os diferentes regimes licitatórios, estabeleceu diversas consequências e sanções por inexecução total ou parcial de grandes obras públicas no Brasil.

Art. 77. A inexecução total ou parcial do contrato enseja a sua rescisão, com as consequências contratuais e as previstas em lei ou regulamento.

Art. 78. Constituem motivo para rescisão do contrato:

I - o não cumprimento de cláusulas contratuais, especificações, projetos ou prazos;

II - o cumprimento irregular de cláusulas contratuais, especificações, projetos e prazos;

III - a lentidão do seu cumprimento, levando a Administração a comprovar a impossibilidade da conclusão da obra, do serviço ou do fornecimento, nos prazos estipulados;

IV - o atraso injustificado no início da obra, serviço ou fornecimento;

$\checkmark$ - a paralisação da obra, do serviço ou do fornecimento, sem justa causa e prévia comunicação à Administração;

VI - a subcontratação total ou parcial do seu objeto, a associação do contratado com outrem, a cessão ou transferência, total ou parcial, bem como a fusão, cisão ou incorporação, não admitidas no edital e no contrato;

VII - o desatendimento das determinações regulares da autoridade designada para acompanhar e fiscalizar a sua execução, assim como as de seus superiores;

VIII - o cometimento reiterado de faltas na sua execução, anotadas na forma do $\S 10$ do art. 67 desta Lei;

IX - a decretação de falência ou a instauração de insolvência civil;

$X$ - a dissolução da sociedade ou o falecimento do contratado;

XI - a alteração social ou a modificação da finalidade ou da estrutura da empresa, que prejudique a execução do contrato;

XII - razões de interesse público, de alta relevância e amplo conhecimento, justificadas e determinadas pela máxima autoridade da esfera administrativa a que está subordinado o contratante e exaradas no processo administrativo a que se refere o contrato;

XIII - a supressão, por parte da Administração, de obras, serviços ou compras, acarretando modificação do valor inicial do contrato além do limite permitido no $\S 10$ do art. 65 desta Lei;

XIV - a suspensão de sua execução, por ordem escrita da Administração, por prazo superior a 120 (cento e vinte) dias, salvo em caso de calamidade pública, grave perturbação da ordem interna ou guerra, ou 
ainda por repetidas suspensões que totalizem o mesmo prazo, independentemente do pagamento obrigatório de indenizações pelas sucessivas e contratualmente imprevistas desmobilizações e mobilizações e outras previstas, assegurado ao contratado, nesses casos, o direito de optar pela suspensão do cumprimento das obrigações assumidas até que seja normalizada a situação;

XV - o atraso superior a 90 (noventa) dias dos pagamentos devidos pela Administração decorrentes de obras, serviços ou fornecimento, ou parcelas destes, já recebidos ou executados, salvo em caso de calamidade pública, grave perturbação da ordem interna ou guerra, assegurado ao contratado o direito de optar pela suspensão do cumprimento de suas obrigações até que seja normalizada a situação;

XVI - a não liberação, por parte da Administração, de área, local ou objeto para execução de obra, serviço ou fornecimento, nos prazos contratuais, bem como das fontes de materiais naturais especificadas no projeto;

XVII - a ocorrência de caso fortuito ou de força maior, regularmente comprovada, impeditiva da execução do contrato.

Parágrafo único. Os casos de rescisão contratual serão formalmente motivados nos autos do processo, assegurado o contraditório e a ampla defesa.

XVIII - descumprimento do disposto no inciso $V$ do art. 27, sem prejuízo das sanções penais cabíveis. (Incluído pela Lei no 9.854, de 1999)

Art. 79. A rescisão do contrato poderá ser:

I - determinada por ato unilateral e escrito da Administração, nos casos enumerados nos incisos I a XII e XVII do artigo anterior;

II - amigável, por acordo entre as partes, reduzida a termo no processo da licitação, desde que haja conveniência para a Administração;

III - judicial, nos termos da legislação; [...]

Art. 80. A rescisão de que trata o inciso I do artigo anterior acarreta as seguintes consequências, sem prejuízo das sanções previstas nesta Lei:

I - assunção imediata do objeto do contrato, no estado e local em que se encontrar, por ato próprio da Administração;

II - ocupação e utilização do local, instalações, equipamentos, material e pessoal empregados na execução do contrato, necessários à sua continuidade, na forma do inciso $\mathrm{V}$ do art. 58 desta Lei;

III - execução da garantia contratual, para ressarcimento da Administração, e dos valores das multas e indenizações a ela devidos;

IV - retenção dos créditos decorrentes do contrato até o limite dos prejuízos causados à Administração (BRASIL, 1993).

Art. 47. Ficará impedido de licitar e contratar com a União, Estados, Distrito Federal ou Municípios, pelo prazo de até 5 (cinco) anos, sem prejuízo das multas previstas no instrumento convocatório e no contrato, bem como das demais cominações legais, o licitante que:

I - convocado dentro do prazo de validade da sua proposta não celebrar o contrato, inclusive nas hipóteses previstas no parágrafo único do art. 40 e no art. 41 desta Lei;

II - deixar de entregar a documentação exigida para o certame ou apresentar documento falso;

III - ensejar o retardamento da execução ou da entrega do objeto da licitação sem motivo justificado; 
IV - não mantiver a proposta, salvo se em decorrência de fato superveniente, devidamente justificado;

$\checkmark$ - fraudar a licitação ou praticar atos fraudulentos na execução do contrato;

VI - comportar-se de modo inidôneo ou cometer fraude fiscal; ou

VII - der causa à inexecução total ou parcial do contrato.

§ 1ㅇ A aplicação da sanção de que trata o caput deste artigo implicará ainda o descredenciamento do licitante, pelo prazo estabelecido no caput deste artigo, dos sistemas de cadastramento dos entes federativos que compõem a Autoridade Pública Olímpica.

$\S 20$ As sanções administrativas, criminais e demais regras previstas no Capítulo IV da Lei no 8.666, de 21 de junho de 1993, aplicam-se às licitações e aos contratos regidos por esta Lei (BRASIL, 2011b).

Aliado a esses dois regimes licitatórios, para os casos de indícios de irregularidades graves que impliquem prejuízo aos cofres públicos (IGP), as sucessivas Leis de Diretrizes Orçamentárias, a partir de 1997, passaram a conter previsão de recomendação para bloqueio de recursos orçamentários para o exercício seguinte. No entanto, as informações fornecidas pelo TCU servem apenas de auxílio aos parlamentares para avaliar a conveniência da interrupção dos recursos orçamentários e a inserir no quadro de bloqueio da Lei Orçamentária Anual (LOA) as obras em que recursos federais deverão ser suspensos no ano subsequente (BRASIL, 2016b). Parece que são nestes dispositivos legais que residem os problemas, pois muitas das obras recomendadas pelo TCU para paralisação muitas vezes não ocorrem, devido à carência e necessidade da população brasileira pelos serviços públicos resultantes dessas obras. Além disso, Ribeiro (2012) acrescenta outros fatores como a certeza de impunidade dos responsáveis pela elaboração de projetos deficientes ou superfaturados e também por falhas na gestão que podem estar associadas a questões estruturais, como falta de recursos humanos, materiais e logísticos, imprescindíveis aos órgãos responsáveis pela contratação e execução dos empreendimentos.

O TCU (BRASIL, 2016b) afirma que as consequências e sanções previstas no sistema normativo licitatório brasileiro são adequados, necessitando haver maior número de fiscalizações pelos órgãos de controle, para melhorar a eficiência na gestão de obras públicas no Brasil. Neste sentido, aponta que isso ocorre pela diminuição de auditores responsáveis pelas fiscalizações, devido à manutenção ou até mesmo diminuição de servidores públicos para atuarem nesta área. Desde 2005, o TCU reclama do aumento de suas atribuições e diminuição no repasse financeiro, ocasionando o deslocamento de seus servidores para atuarem em outras áreas que não a fiscalização das obras públicas. 


\section{CONCLUSÕES}

É inegável a importância do sistema normativo licitatório brasileiro e o papel do Tribunal de Contas da União (TCU) e outros órgãos de controle na fiscalização de grandes obras públicas para maximizar a eficiência no uso do dinheiro público no Brasil. No entanto, tais mecanismos de controle não estão sendo efetivos para evitar irregularidades nas grandes obras públicas no País, seja por problemas e lacunas normativas, deficiência na gestão pública, corrupção, falta de fiscalização ou diminuição na arrecadação e repasses financeiros em todos os setores, o fato é que a situação das grandes obras públicas no Brasil é extremamente preocupante.

Em relação à metodologia de amostragem das obras públicas a serem fiscalizadas pelo TCU no Brasil, esta não é bem clara e deveria ser melhor demonstrada para se evitar favorecimentos e mascaramentos da real situação brasileira. Neste sentido, o Índice de Desenvolvimento Humano Municipal (IDH-M) poderia ser incluído na metodologia de amostragem das fiscalizações de obras públicas pelo TCU.

Em média, 65\% das obras públicas fiscalizadas apresentaram irregularidades graves e apenas 8\% não apresentaram problemas no Brasil. Em média, as áreas em que mais ocorrem irregularidades são no processo licitatório, seguido do projeto básico ou executivo. Essas fases são anteriores à execução propriamente dita da obra, por isso revelam problemas do gestor público no planejamento licitatório. Outras áreas que mereceram destaque negativo foram sobrepreço/superfaturamento e execução da obra, que indicam problemas com o contratado.

Não houve diferença significativa entre o regime licitatório proporcionado pelo Regime Diferenciado de Contratações Públicas (RDC) em relação ao regime estabelecido pela Lei no 8.666/93 para diminuir irregularidades de quaisquer tipos nas grandes obras públicas no Brasil, entre 2014 e 2016.

Há possíveis soluções para minimizar tais irregularidades a curto prazo, sem adentrar na questão econômico-orçamentária, como aumentar as fiscalizações, e é claro nos problemas de gestão, planejamento e corrupção.

Dentre as quais, realizar mudanças na Lei no 12.462/2011, que instituiu o RDC, quanto a flexibilização normativa da obediência aos atuais sistemas referenciais de custos. Esse artifício legal é utilizado pelos contratantes para realizar a chamada contratação integrada, que permite a concentração do projeto básico, projeto executivo e execução da obra em um mesmo 
contratante, tornando facultativa a utilização de vários mecanismos de controle como o registro de preços.

Outro problema que demanda solução é que a recomendação fornecida pelo TCU para paralisação de obras públicas chave, em que há flagrante prejuízo ao erário, e o bloqueio de recursos orçamentários para o exercício seguinte, não é vinculante. A conveniência de tais medidas cabe aos parlamentares que muitas vezes não a acatam. Fornecer maior poder vinculante às decisões prolatadas pelo TCU, que é o órgão que dispõe de informações técnicas para emiti-las, poderia aumentar sua autonomia.

\section{REFERÊNCIAS}

ALTOUNIAN, C. S. Obras públicas: licitação, contratação, fiscalização e utilização. 5 eds., Belo Horizonte: Fórum, 2016.

BRASIL. Acórdão do Tribunal de Contas da União no 2.928 de 30 de outubro de 2012. TC 033.616/2011-6. Trata-se de consolidação das fiscalizações de obras públicas realizadas pelo Tribunal de Contas da União (TCU) no âmbito do Fiscobras 2012, para fins de cumprimento da Lei 12.708, de 17/8/2012 (LDO/2012).

Acórdão do Tribunal de Contas da União no 2.969 de 06 de novembro de 2013. TC 041.274/2012-1. Trata-se de consolidação das fiscalizações de obras públicas realizadas pelo Tribunal de Contas da União (TCU) no âmbito do Fiscobras 2013, para fins de cumprimento da Lei 12.708, de 17/8/2012 (LDO 2013).

Acórdão do Tribunal de Contas da União no 3.143 de 05 de novembro de 2014. TC 011.169/2013-3. Trata-se de consolidação das fiscalizações de obras públicas realizadas pelo Tribunal de Contas da União (TCU) no âmbito do Fiscobras 2014, para fins de cumprimento da Lei 12.919, de 24/12/2013 (LDO 2014).

Acórdão do Tribunal de Contas da União no 2.809 de 04 de novembro de 2015. TC 029.823/2014-5. Trata-se de consolidação das fiscalizações de obras públicas realizadas pelo Tribunal de Contas da União (TCU) no âmbito do Fiscobras 2015, para fins de cumprimento da Lei 13.080, de 02/01/2015 (LDO 2015).

Acórdão do Tribunal de Contas da União no 2.810 de 04 de novembro de 2016. TC 011.421/2015-0. Trata-se de consolidação das fiscalizações de obras públicas realizadas pelo Tribunal de Contas da União (TCU) no âmbito do Fiscobras 2016, para fins de cumprimento da Lei 13.242, de 30/12/2015 (LDO 2016).

Fiscobras 2016: fiscalização de obras públicas pelo TCU, 20 ano. Brasília: Tribunal de Contas da União, 2016b.

Lei no 8.666, de 21 de junho de 1993. Regulamenta o art. 37, inciso XXI, da Constituição Federal, institui normas para licitações e contratos da Administração Pública e dá outras providências.

Lei no 12.462, de 04 de agosto de 2011. Institui o Regime Diferenciado de Contratações Públicas.

Lei no 13.242, de 30 de dezembro de 2015b. Dispõe sobre as diretrizes para a elaboração e execução da Lei Orçamentária de 2016 e dá outras providências. 
Licitações e contratos: orientações e jurisprudência do TCU. 4. ed. Brasília: Tribunal de Contas da União. Secretaria Especial de Editoração e Publicações, 2010.

Ministério Público Federal. Ação direta de inconstitucionalidade № 4.655, de 07 de setembro de 2011c. Impugna a Lei no 12.462, de 05 de agosto de 2011.

Obras públicas: recomendações básicas para a contratação e fiscalização de obras públicas. 3 ed. Brasília: Tribunal de Contas da União, 2013b.

CELESTINO, F.K.R. Regime diferenciado de contratações: breves comentários à exceção que virou tendência. Revista Controle, v. 10, n. 2, p. 170-201, 2012.

JUSTEN FILHO, M. Comentários à lei de licitações e contratos administrativos. 17 ed. São Paulo: Revista dos Tribunais, 2016.

MELLO, C.A.B. Curso de direito administrativo. 33 ed. São Paulo: Malheiros, 2016.

PIETRO, M.S.Z. Direito administrativo. 30 ed. Rio de Janeiro: Forense, 2017.

PNUD - Programa das Nações Unidas para o Desenvolvimento. Desenvolvimento humano nas macrorregiões brasileiras. Brasília: IPEA, 2016.

RIBEIRO, R. A lenta evolução da gestão de obras públicas no Brasil. E-legis, v. 5, n. 8, p. 82-103, 2012.

Trabalho enviado em 01 de agosto de 2017.

Aceito em 12 de novembro de 2017. 